Article

\title{
Disaster, Displacement and International Law: Legal Protections in the Context of a Changing Climate
}

\author{
Miriam Cullen \\ Faculty of Law, University of Copenhagen, 2300 Copenhagen, Denmark; E-Mail: miriam.cullen@jur.ku.dk
}

Submitted: 31 May 2020 | Accepted: 14 July 2020 | Published: 10 December 2020

\begin{abstract}
As the number of people displaced by disaster reaches record highs, this article describes how international law is relevant to disaster displacement, how refugee law is probably not the answer, and synthesises recent developments into contemporary application. New interpretations of international human rights law have advanced legal protections such that planning and preparedness to address future disasters now form an express component of states' international legal obligations. At the same time, climate change is increasing the frequency and intensity of extreme weather events, exacerbating factors that cause disaster and displacement and rendering the effective implementation of international law more difficult. The further 'othering' of migrants during the Covid-19 pandemic could stymie the realisation of protections as national governments close borders, anti-immigration sentiment is stoked, and economies decline.
\end{abstract}

\section{Keywords}

climate change; disaster; displacement; international law; migration

\section{Issue}

This article is part of the issue "The Politics of Disaster Governance" edited by Dorothea Hilhorst (Erasmus University Rotterdam, The Netherlands), Kees Boersma (Vrije Universiteit Amsterdam, The Netherlands) and Emmanuel Raju (University of Copenhagen, Denmark).

(C) 2020 by the author; licensee Cogitatio (Lisbon, Portugal). This article is licensed under a Creative Commons Attribution 4.0 International License (CC BY).

\section{Introduction}

Although disaster-related displacement is not new, it is undoubtable that climate change and the associated increased incidence of extreme weather events amplify the risk (Adger et al., 2014, pp. 758, 768). Yet the multifaceted nature of mobility makes it an almost impossible phenomenon to forecast with any precision. Specific displacement impacts of climate change are equally unpredictable because the effects of climate change are not linear and will rarely be the single influencing factor (Bohra-Mishra, Oppenheimer, \& Hsiang, 2014; McLeman, 2018). Still, there is high scientific agreement that climate change impacts will contribute to contemporary human mobility into the future (Pörtner et al., 2019, p. 396). A recent study has predicted that absent climate mitigation or migration, between one billion and three billion people will reside outside the "temperature niche" favourable to human life by 2070 (Xu, Kohler, Lenton, Svenning, \& Scheffer, 2020). We are already wit- nessing these effects. Of the 33.4 million people internally displaced in 2019, 24,9 million were displaced by disaster (Internal Displacement Monitoring Centre, 2020a, p. 9). Because internal displacement is often the precursor for cross-border displacement, a comprehensive approach to disaster displacement ought to consider both (Internal Displacement Monitoring Centre, 2020b, p. 5; Nansen Initiative, 2015, pp. 8, 32-41).

This article examines the international legal protections available to people displaced by disaster in the context of recent and notable legal developments. A groundswell of international instruments over the past decade have incorporated express recognition of the nexus between disaster and displacement into their terms. Moreover, the United Nations (UN) Human Rights Committee's January 2020 decision on non-refoulement obligations, the 2018 Global Compact for Safe, Orderly and Regular Migration (hereafter Migration Compact), and evolving interpretations of the right to life, have advanced contemporary legal thinking on the legal pro- 
tections owed. The article first clarifies its scope and provides a primer on the legal landscape, followed by a short section explaining the limited relevance of refugee law. It then addresses recent legal developments, including the UN Human Rights Committee's January 2020 decision on non-refoulement obligations, and the increased legal recognition of the nexus between disaster preparedness and human rights protection. The penultimate section examines how the increased frequency and intensity of extreme weather events can further diminish state capacity to honour its international legal obligations, before final conclusions are drawn.

The word 'disaster' attracts various interpretations in international law. The 2016 International Law Commission (ILC) Draft Articles on the Protection of Persons in the Event of Disaster, for example, defines disaster in line with the idea that a disaster is an event that causes harm of a gravity to constitute a serious disruption to the functioning of society (ILC, 2016, Art. 3(a)). The ILC acknowledged that its approach went against contemporary thinking about disaster but was of the view that the more modern conceptualisation, which perceives disaster as the consequence of the event, would be too broad to be legally meaningful (ILC, 2016, commentary on Art. 3(a), para. 3). Yet earlier international instruments interpreted disaster in line with the modern construction, (see for example the Tampere Convention on the Provision of Telecommunication Resources for Disaster Mitigation and Relief Operations, 1998, Art. 1(6); hereafter Tampere Convention). The contemporary approach responds to the long-held concern that to define disaster as an event fails to consider the socio-economic, political and other societal conditions that contribute to individual or household vulnerability (see, for example, Cannon, 1994).

This article adopts the interpretation adopted by the UN General Assembly's intergovernmental expert working group on indicators and terminology relating to disaster risk reduction. It defined disaster as:

A serious disruption of the functioning of a community or a society at any scale due to hazardous events interacting with conditions of exposure, vulnerability and capacity, leading to one or more of the following: human, material, economic and environmental losses and impacts. (UN General Assembly, 2016, p. 13)

The proviso that the disaster must "exceed the capacity of the community or society to cope using its own resources" has been used elsewhere with reference to cross-border displacement (Nansen Initiative, 2015), but would narrow the construction too far for present purposes. A more expansive conceptualisation allows discussion of the law governing both internal displacement as well as cross-border movement. It also permits consideration of the broad swathe of climate change-related displacement-causing events, whether sudden onset or slow onset in character. That is not to say that this defini- tion is to be preferred generally, the parameters of which will inevitably depend upon the context in which it is used and the character and purpose of the relevant law.

There is no single international instrument that provides a legal basis for the protection of individuals who are displaced by disaster. Despite some calls for an international agreement (Docherty \& Giannini, 2009; Prieur, 2018) there does not appear to be much contemporary appetite for one, even within the legal community (Mayer, 2011, 2013; McAdam, 2011; Nishimura, 2015). This is in part due to the absence of any clear and agreed definitions of who would fall within the relevant protected category (be it 'disaster migrant,' 'climate refugee' or something else) and the problems associated with creating such boundaries (Apap, 2019; Mayer, 2018). In particular there is a tension between ensuring a definition that is sufficiently confined as to be legally meaningful, and at the same time accounting for the "complex causality of climate migration and the heterogeneity of the phenomena it encompasses" (Mayer, 2013, p. 98).

One could argue that this article's preoccupation with law is misplaced insofar as international policy processes have advanced normative gapfilling and cultivated effective practices for the protection of people displaced by disaster. The state-led Nansen Initiative (2012-2015), for instance, developed a detailed approach to cross-border disaster displacement, which incorporated best practice, and identified normative gaps. The resultant Agenda for the Protection of Cross-Border Displaced Persons in the Context of Disasters and Climate Change (hereafter Protection Agenda) was endorsed by 109 states and provided the architecture for the work of its successor process, the Platform on Disaster Displacement (see further, McAdam, 2016). Another example, the Taskforce on Displacement, is a small group of experts tasked with guiding the Warsaw International Mechanism for Loss and Damage Associated with Climate Change to enhance "cooperation and facilitation in relation to human mobility, including migration, displacement and planned relocation" (UN Framework Convention on Climate Change [UNFCCC], 2015, para. 49; UNFCCC, n.d., para. 5). It is important to recall that the relationship of such processes to international law is complementary, not dichotomous. Law is typically informed by, and often lags behind, policy developments. In that sense, these processes will likely feed into any future legal agreements. Moreover, legal norms, particularly those in human rights, have provided the baseline from which policy recommendations have grown.

Indeed, it is no longer completely correct to remark that "in the absence of commonly agreed standards, the disaster victim is at the mercy of the vagaries of the humanitarian response, political calculation, indifference or ignorance" (Hoffman, 2000, p. 145). The past 20 years have seen the international approach to disaster shift from one which occurred within the context of legal exceptionalism-treating disaster as an anoma- 
lous condition during which exceptions to international law apply-towards one grounded in existing and emerging legal frameworks (Lauta, 2015, p. 75). The potential of international law to advance the response to and avoidance of disaster is evidenced by the various international legal agreements and instruments that have been concluded on the topic. Traditionally, many of these have taken a top-down logistical approach, without necessarily affording specific protection to individuals, notwithstanding that compliance with their terms would likely preserve human life. Examples of such agreements include the Hyogo Framework for Action 2005-2015 and its successor the Sendai Framework for Disaster Risk Reduction 2015-2030 (hereafter Sendai Framework) which focus on disaster management and disaster risk management, as well as binding treaties with more specific focus such as the Tampere Convention mentioned above.

Another category of international agreement is those that concern the protection of individuals, or a category of individuals, and have incorporated consideration of disasters into one or more of their provisions in ways that might be relevant for displaced individuals who fall within their terms. Article 11 of the Convention on the Rights of Persons with Disabilities (2006), for instance, provides that parties shall take all necessary measures to ensure the protection and safety of persons with disabilities in situations of risk, including "humanitarian emergencies and natural disasters." The Declaration on the Rights of Peasants, adopted by the UN General Assembly in 2018, provides that states "shall take appropriate measures to strengthen the resilience of peasants and other people working in rural areas against natural disasters and other severe disruptions" (Declaration on the Rights of Peasants and Other People Working in Rural Areas, 2018, Art. 16(5)). Of particular relevance, the Migration Compact contains several paragraphs that address methods to mitigate disaster-related displacement, which are considered later in this article (Migration Compact, 2018, para. 18).

These categorisations are neither perfect nor exhaustive. The point for now is simply to illustrate that while international law governing disaster preparedness and response has grown, for better or worse no international instrument contains as its focus legal protections for people displaced by disaster. Instead, their protection is derived from a patchwork of new and existing legal instruments, usually not specific to disaster but simply applied in the context of one. This article explains the scope and limitations of that law, beginning with refugee protection and the principle of non-refoulement under human rights law.

\section{Refugee Law and Disaster Displacement}

The Convention Relating to the Status of Refugees (1951; hereafter Refugee Convention) offers the strongest protection under international law for people who cross an international border seeking protection. This is because, among other things, of the Refugee Convention's wide ratification, its long history, and that it ensures a series of specific protections such as the right to employment, public education and social security (see Refugee Convention, 1951, Chapters III-IV). Yet, in contrast to the popularity of the term 'climate refugee' (addressed further below), the Refugee Convention will very rarely offer individual protection for people displaced by disaster (see, e.g., McAdam, 2012; Nishimura, 2015; Philip, 2018). A refugee is a person who is outside the country of his nationality and, owing to a well-founded fear of persecution on the grounds of race, religion, nationality, membership of a particular social group or political opinion, is unwilling to avail himself of the protection of that country (Refugee Convention, 1951, Art. 1A). Any claim for refugee status on the grounds of the disaster event alone will prima facie fail: It is not persecution, and fleeing disaster does not qualify a person for refugee status under the Refugee Convention ( $A H$ (Sudan) v. Secretary of State, 2007; Applicant A v. Minister of Immigration and Multiethnic Affairs, 1998; McAdam, 2012, pp. 42-48).

However where a state's response to disaster fails to meet the needs of marginalized groups, that situation could give rise to persecution within a Convention meaning and open to the door to refugee status ( $A F$ (Kiribati), 2013, para. 58; McAdam, 2012). So too could refugee status become an active question in the context of a nexus between climate change and armed conflict, or under the broader definition of 'refugee' under the two main regional refugee agreements, in which the term is extended to include people fleeing events or circumstances "seriously disturbing public order" (Cartagena Declaration on Refugees, 1984, para. 3; Convention Governing Certain Aspects of Refugee Problems in Africa, 1969, Art. 1(2); Weerasinghe, 2018).

These are legally arguable exceptions to the general rule that people moving for disaster-related reasons will not meet the criteria for refugee status. However, they are rarely argued and have not so far given rise to refugee status having been granted. Thus, although a disaster would seem to be a prima facie case of an event seriously disturbing public order, no states have expressly recognised this as triggering their refugee obligations under the regional definitions. Instead, states have tended to enact temporary protection under domestic law (Weerasinghe, 2018).

The limited scope of refugee law leaves behind a widely recognised 'protection gap,' including for people displaced by disaster (Behrman \& Kent, 2018; Kolmannskog \& Trebbi, 2010; Kuusipalo, 2016; Philip, 2018). So why does the phrase 'climate refugee' continue to feature prominently in public discourse when it is widely accepted that refugee status will rarely apply? There is not scope to answer this question comprehensively here, but it would be remiss not to offer a few brief points on terminology given the prevalence of the phrase. First, the use of the word 'climate' preceding 
the word 'refugee' narrows the focus to a particular kind of disaster. Disaster is, of course, not exclusively weather or climate related, as centuries of armed conflict and the current Covid-19 pandemic evince. Nevertheless, outside war-which has its own comprehensive legal regime-weather (and therefore also climate) accounts for the bulk of people displaced by disaster (Internal Displacement Monitoring Centre, 2020a).

As outlined above, the word 'refugee' is the subject of a well-established and widely accepted legal regime. For those advocating for the systematic and comprehensive protection of people displaced by disaster, refugee status is arguably the strongest mechanism through which individuals in need of protection who have crossed an international border can receive that protection outside their own state. On the other hand, recipient-states commonly perceive the cross-border movement of people as a potential security threat. In this way, the concept of 'climate refugee' is argued to be a "calculated ambiguity deployed by certain actors and agencies, especially in the global North, to mark the boundaries between 'our space' and 'their space"' (Gregory, 2009, pp. 369-370, as cited in Doyle \& Chaturvedi, 2011, p. 288). It reinforces a traditional North-South security paradigm where "the supposedly rational North tends to be positioned normatively in control in relation to 'chaotic' southern states" (Farbotko, 2017, p. 75). People displaced by climaterelated disaster are constructed as embodying "a danger for receiving states, not for the displaced themselves" (Farbotko, 2017, p. 75). Thus, the potential for refugee status is both an advocacy tool for those concerned with the rights of people on the move, and a point of resistance for states reluctant to receive them.

\section{Non-Refoulement and the 2020 Decision of the UN Human Rights Committee}

The principle of non-refoulement under international human rights law offers limited protection against return where an individual has survived the initial disaster and fled across an international border. It arises in circumstances where to be returned would give rise to a threat to life, torture, or cruel, inhuman or degrading treatment in contravention of Articles 6 and 7 of the International Covenant on Civil and Political Rights (ICCPR) or Article 3 of the Convention Against Torture and Other Cruel, Inhuman or Degrading Treatment or Punishment (UN Human Rights Committee, 2004, para. 12). The obligation is on the receiving state not to return that person to their disaster-affected home state. However, we are yet to see a single successful case where non-refoulement has been expressly activated on these grounds.

The January 2020 decision of the UN Human Rights Committee is the most significant legal decision on the nexus between non-refoulement and disaster to date (UN Human Rights Committee, 2020). In it, the Committee was asked to consider the extent to which the right to life could activate non-refoulement protections in the context of slow-onset disaster. In this case a national of the small island state of Kiribati argued that in returning him to Kiribati, New Zealand violated its non-refoulement obligations under international law because the effects of sea level rise in his home state violate his right to life. The Committee accepted the claimant's evidence that sea level rise caused by climate change posed a threat to the islands. Fresh water had become scarce and was often contaminated, the construction of sea walls had been largely ineffective against storm surges and king tides, and there had been instances of violence caused by land disputes in tensions exacerbated by the environmental conditions. However, the Committee, by majority (16 of 18 members), rejected the claim. It found that potable water, while scarce, was nevertheless sufficiently available; that the threat of violence was not sufficiently personal to the claimant; and that although salt-water inundation of the soil made it "difficult to grow crops, it was not impossible" (UN Human Rights Committee, 2020, para. 4.6). Overall, the Committee was not convinced that the claim demonstrated a level of "extreme precarity" sufficient to threaten his right to life (UN Human Rights Committee, 2020, para. 9.9). However, it left open the possibility of protection if, and when, the situation worsens.

Notably, two separate dissenting opinions expressed the view that New Zealand's non-refoulement obligations were violated on the evidence before them: Individual opinion of Committee member Vasilka Sancin (dissenting), and separate individual opinion of Committee member Duncan Laki Muhumuza (dissenting; UN Human Rights Committee, 2020, Annexes 1-2). The dispute between the minority and the majority appeared to be one of degree, that is, at what point of "precarity" non-refoulement obligations are triggered. In the dissenting opinion of member Muhumuza:

The considerable difficulty in accessing fresh water because of the environmental conditions, should be enough to reach the threshold of risk, without being a complete lack of fresh water.....t would indeed be counterintuitive to the protection of life, to wait for deaths to be very frequent and considerable; in order to consider the threshold of risk as met. (UN Human Rights Committee, 2020, Annex 2, para. 5)

Although the decision was in many respects a restatement of existing principles of international law, what is important about the Committee's ruling is that it offers an authoritative statement of the connection between the disaster-related impacts of climate change and the principle of non-refoulement (McAdam, 2020). As McAdam has observed, the decision also left scope for the possibility that "a different individual, in another part of the world, might already have a valid protection claim" (McAdam, 2020, p. 3). Finally, the dissenting opinions offer some fodder for future debate about whether 
the non-refoulement obligations of a state might apply at an earlier point than was recognised by the majority.

\section{Internal Displacement and recent Developments in Legal Protections}

Most people displaced by disaster remain within the state in which the disaster occurred. For internally displaced people (IDPs), refugee law and non-refoulement are not applicable unless and until they cross an international border. There is very little binding international law which addresses internally displaced people specifically. The 1998 Guiding Principles on Internal Displacement (GPID) were the first comprehensive assessment of protections for IDPs under international law. The GPID offered guidance on the interpretation of extant principles of international humanitarian law and international human rights law in the context of internal displacement. The only treaty the subject matter of which is protection for IDPs is the 2009 African Union Convention for the Protection and Assistance of Internally Displaced Persons in Africa. For the rest of the world, there are no binding instruments of international law on point, although human rights obligations continue to apply. Recognising this protection gap, and the exponential growth in the number of IDPs in 2019, the UN Secretary-General convened a High Level Panel on Internal Displacement (hereafter the Panel) in December of that year. Comprised of eight state representatives advised by a small Expert Group, the Panel's central focus is to find long-term solutions to, raise awareness of, and improve efforts to address, internal displacement. The Panel is due to submit its final recommendations in February 2021, one year after its first meeting (UN, 2020; UN Secretary-General, 2019).

Although disaster is not the exclusive focus of the Panel's work, its appointment came on the heels of exponential growth in the number of people internally displaced by disaster (Internal Displacement Monitoring Centre, 2020a) and a growing number of international instruments addressing disaster displacement in the past decade. Language connecting disaster and displacement was incorporated into the Cancun Agreement of the Conference of the Parties to the UN Framework Convention on Climate Change (UNFCCC, 2011, para. 14(f)), the Sendai Framework (2015, paras. 4, 28(d), 33(h)(j)), the New York Declaration for Refugees and Migrants $(2016$, paras. $1,18,43,50)$ and the subsequent global compact agreements in 2018 (Global Compact on Refugees, 2018, paras. 8, 9, 12, 53, 63, 79; Migration Compact, 2018, in particular para. 18(h)-(I)). As referred to above, global processes were also created to address disasters and displacement, including the Nansen Initiative (2012-2015) which was succeeded by the Platform on Disaster Displacement, and the 2015 Paris Outcome established the Taskforce on Displacement under the auspices of the UNFCCC (2015, para. 49). A common element within each of these instru- ments and processes is recognition that the mitigation of displacement is closely connected to disaster risk reduction, and grounded in principles of human rights.

Disaster risk reduction as an express component of international human rights law and international migration law is a reasonably new development, but one which has corresponded to the growth of international law in the context of disaster. Until recently such protections were largely implicit in human rights law as part of the accepted principle that states have an obligation not only to refrain from violating human rights, but also to take positive steps to protect them (see Budayeva and Others v. Russian Federation, 2008, para. 128; Öneryildiz v. Turkey, 2004, para. 71; UN Human Rights Committee, 2004, para. 6). More recently, human rights bodies have made express the connection between disaster risk reduction and human rights. In a 2017 Advisory Opinion, the Inter-American Court of Human Rights (IACtHR) recognised that, as part of the right to life, states are under a duty to "prepare a contingency plan" in environmental impact assessments for activities likely to pose a risk to the environment. The purpose of such contingency plans is, among other things, to "minimize the consequences of disasters" (IACtHR, 2017, paras. 171, 242). The Advisory Opinion was confined to matters relevant to the advice for which it was sought. Thus it was a significant development when, in 2018, the UN Committee responsible for interpretation of the ICCPR issued a revised guidance on the interpretation of the right to life generally, which included disaster preparedness elements. It provided that in fulfilling their duty to protect life, states "should...develop, when necessary, contingency plans and disaster management plans designed to increase preparedness and address natural and manmade disasters, which may adversely affect enjoyment of the right to life" (UN Human Rights Committee, 2018, para. 26). In this way, the Committee for the first time expressly read a disaster preparedness element into the state obligation to protect the right to life.

The 2018 Migration Compact is the first international migration agreement negotiated between states to include a commitment to mitigate the displacement effects of disaster. Under the heading "natural disasters, the adverse effects of climate change, and environmental degradation," states commit to "minimize the adverse drivers and structural factors that compel people to leave their country of origin" (Migration Compact, 2018, para. 18(h)-(I)). Included among the strategies to realise that commitment are: to strengthen analysis and mapping of climate and disaster risk; to develop adaptation, resilience and disaster preparedness strategies; and to develop approaches to address sudden and slow-onset disasters which take into account processes such as the Nansen Initiative's Protection Agenda and the work of the Platform on Disaster Displacement. Moreover, states commit to developing approaches at regional and subregional levels to ensure that people impacted by disaster "have access to humanitarian assistance that meets 
their needs with full respect for their rights wherever they are" (Migration Compact, 2018, para. 18(k)). Although the Migration Compact itself is not strictly legally binding, it is a political commitment which 'rests on' international law, including core human rights instruments listed in its preamble: the Universal Declaration of Human Rights, the ICCPR, and the International Covenant on Economic, Social and Cultural Rights (Migration Compact, 2018, Preamble, para. 2).

The past decade has seen several advancements in protections for people internally displaced by disaster, resting particularly on human rights norms. A number of international instruments now recognise the nexus between disaster and displacement in express terms and disaster risk reduction has become an explicit component of the state obligation to protect life. The Migration Compact specifically acknowledges that disaster preparedness, addressing vulnerabilities, and human rights protection, are key elements in protecting people from disaster-related displacement. These developments are not only significant in law, they coincide with a substantial increase in the incidence of disaster displacement and therefore have the potential for meaningful impact to the extent that states adapt domestic law and policy accordingly.

\section{Challenges for Upholding International Legal Protections in the Context of a Changing Climate}

Notwithstanding the foregoing, a series of contemporary realities hinder the realisation of protections for people displaced by disaster. A reversion to isolationist politics in large migrant-receiving states (AndersonNathe \& Gharabaghi, 2017), domestic prejudices exacerbated by the recent pandemic (Larsson, 2020), and the perennial difficulties associated with humanitarian access and the enforcement of international law, are but a few (Koh, Chayes, Chayes, \& Franck, 1997; Silingardi, 2012). There is not scope here to focus on all of these, important though they are. This section instead considers the legal impact of a single but critical challenge for a state's capacity to ensure effective protection of people displaced by disaster in accordance with international law: climate change.

We know that most disaster-related internal displacements are associated with ocean and rainfall events such as tropical cyclones and monsoons (Internal Displacement Monitoring Centre, 2020a, p. 8). Rising ocean temperatures have made cyclones more intense, and rising sea levels have intensified storm surges, and saltwater inundation has caused the salination of previously arable soil and contaminated fresh water supply (Pörtner et al., 2019, p. 91). A recent report of the Intergovernmental Panel on Climate Change indicates that earlier scientific predictions underestimated the speed with which climate change impacts would be realised (Pörtner et al., 2019, p. 106). We also know that the vast majority of people who are displaced by disaster tend to remain within the same region, thus still proximate to the same climate phenomena. Yet, the durability of cross-border regional solutions can be challenged where neighbouring states are at risk of the same or similar climate-related events. As a result, climate change leads to not only more numerous instances of displacement but also to the risk of repeated ones (Nansen Initiative, 2015, para. 75).

That some people are displaced more than once is not a new finding; it is already well-documented in the context of other indices of vulnerability and displacement (Zetter \& Morrissey, 2014). Migrant populations are often among the most seriously affected by disaster or climate-related events (Simperingham, 2017, p. 88). Refugee camps in Bangladesh and Syria have recently experienced severe flooding from unusually heavy rainfall which rendered encampments unliveable, even lifethreatening (Kelly, 2019; "Monsoon destroys Rohingya shelters," 2019). But climate change increases the instances in which initial and subsequent displacement is disaster related. Indeed, for residents of small island states and low-lying coastal areas, inundation caused by sea level rise can trigger a series of displacements over time, where each movement is neither durable nor necessarily distant, but rather only so far as circumstances permit and the ocean demands (McDonnell, 2019; Rigaud et al., 2018, p. xv). Repeated disasterrelated displacement challenges the effective implementation of protection obligations because, among other things, it renders the logistics of providing assistance, as well as monitoring and compliance, more challenging.

As the preceding sections of this article attest, in the context of international law, human rights norms govern or underpin much of the law applicable to people displaced in the context of disaster. Indeed, the principle of non-refoulement, the Migration Compact, the GPID, and the Sendai Framework and other relevant instruments are premised, in whole or in part, upon binding human rights norms. Yet disaster itself compromises state capacity generally. A question then arises: To what extent can a state be expected to uphold its international legal obligations in the context of disaster? This is not a new consideration but one worth cautiously observing in the present context. In general, states may derogate from human rights obligations only temporarily and in situations of declared public emergency that threaten the life of the nation to the extent required by the exigencies of the situation (American Convention on Human Rights, 1969, Art. 27; European Convention on Human Rights, 1950, Art. 15; ICCPR, 1966, Art. 4). Thus, it is prima facie recognised in human rights law itself that the full observation of some rights might need to be curtailed to allow an effective disaster response. At the same time, it is during purported public emergencies that the most egregious human rights abuses have occurred (Joseph \& Castan, 2013, p. 910). Thus, the boundaries of what is permissible ought to be carefully and consciously observed. 
Notably, some rights cannot be derogated from at all, even during a public emergency that threatens the life of the nation. These include, but are not limited to, the right to life, and freedom from cruel inhuman or degrading treatment (American Convention on Human Rights, 1969, Art. 27(2); European Convention on Human Rights, 1950, Art. 15(2); ICCPR, 1966, Art. 4(2)). Accordingly, the principle of non-refoulement, which is premised upon these two rights, applies even in the aftermath of disaster. A recent case study is illustrative of the issues that can arise in practice. Hurricane Dorian made landfall in The Bahamas on 1 September 2019. The damage was catastrophic, with a fifth of the population impacted and over 9,000 homes destroyed. Among the worst affected were Haitians, and Bahamas-born nationals of Haitian descent. Historic marginalisation has meant that Haitians in The Bahamas often live in poverty, without access to basic services such as running water (Internal Displacement Monitoring Centre, 2020a, p. 61). Before the hurricane, and in line with its protection obligations, The Bahamas had suspended repatriation of irregular Haitian arrivals in 2019 due to ongoing civil unrest in Haiti. It assessed that to return irregular migrants would be a violation of the principle of non-refoulement. However, after the hurricane, repatriations of irregular Haitian arrivals resumed in earnest (International Organization for Migration, 2019).

The Internal Displacement Monitoring Centre has reported that Haitians are at greater risk as immigration authorities have "taken advantage of the disaster" to enforce immigration policy and deport undocumented Haitians (Internal Displacement Monitoring Centre, 2020a, p. 61). According to the Internal Displacement Monitoring Centre, The Bahamas authorities have implied that because Haitian people are not citizens they "should not...be considered internally displaced or entitled to support and compensation" (Internal Displacement Monitoring Centre, 2020a, p. 61). Given The Bahamas' earlier determination that the repatriation of irregular arrivals would violate its non-refoulement obligations, to resume repatriations immediately after the hurricane is worthy of scrutiny. If the Haitian nationals being repatriated in the aftermath of Hurricane Dorian would face threats to the right to life or right to freedom from torture, cruel, inhuman or degrading treatment if they were returned, then their repatriation would be unlawful. That is so irrespective of any additional resource burden this might place on the state of The Bahamas in the aftermath of the hurricane.

How, then, can a state comply with human rights obligations in circumstances where the apparatus of the state, and its capacity to respond, are severely diminished not only by disaster itself but by repeated and more intense events? The Draft Articles on the Protection of Persons in the Event of Disasters (hereafter Draft Articles), adopted by the ILC in 2016, offer some guidance. The purpose of the Draft Articles is to "facilitate the adequate and effective response to disasters and reduc- tion of the risk of disasters, so as to meet the essential needs of the persons concerned, with full respect for their rights" (ILC, 2016, Art. 2). "Persons concerned" includes people displaced by disaster or likely to be displaced by a future disaster (ILC, 2016, p. 5). Crucially, the Draft Articles delineate for the first time a state duty to seek external assistance where the disaster "manifestly exceeds its national response capacity" (ILC, 2016, Art. 11) and the obligation not to arbitrarily withhold consent permitting external assistance (ILC, 2016, Art. 13). Although the Draft Articles are essentially a draft treaty, yet to be adopted by states, they offer some indication of what the current state of customary international law might be, in line with the role delegated to it by the UN General Assembly to encourage the codification of international law (Charter of the United Nations, 1945, Art. 13; United Nations General Assembly, 1945, Art. 1). However, its role is also to encourage the progressive development of international law and there has been some debate among states within the Sixth Committee of the General Assembly over which elements of the Draft Articles represent custom and which might be better described as progression. The General Assembly is due to debate the terms of the Draft Articles again this year (UN General Assembly, Sixth Committee, 2019).

\section{Conclusion}

Translating international law into meaningful application on the ground is a perennial challenge, and one only exacerbated in the context of disaster. Many of the regions most effected by displacement from disaster have limited state capacity to plan and prepare, and often possess numerous indices of vulnerability such as hazard exposure, low socio-economic status among the populace, and poor infrastructure development (Fatemi, Ardalan, Aguirre, Mansouri, \& Mohammadfam, 2017). The impacts of climate change amplify these. Sea level rise, drought, increased intensity of storms, storm surges and their consequent effects such as contamination of water supplies, and the loss of arable land, lead not only to more numerous instances of displacement but also to the risk of repeated displacement of the same people. It is undoubtedly more difficult to uphold and ensure international legal protection for people who are recurrently on the move, and even more so where that displacement occurs within a state or region facing more than one crisis.

In this context, the Covid-19 pandemic is a sobering case study and a reminder of the importance of preparedness and disaster risk reduction. The pandemic has had serious implications for the realisation of legal protections owed to individuals displaced by non-pandemic-related disaster. As was recently experienced in the aftermath of Cyclone Amphan, which hit the Bay of Bengal in the midst of the pandemic: It is difficult to respond to a disaster, and in particular to accommodate people displaced, while maintaining appropri- 
ate social distancing (Sarkar, 2020). To the extent that states continue to lag in terms of disaster preparedness, displaced communities will struggle to receive protection whether within their own state or in the state to which they have migrated. In many traditional migrantreceiving states, borders have closed in response to the virus to protect local populations from infection while xenophobic sentiment has escalated and furthered the 'othering' of migrant communities (Devakumar, Shannon, Bhopal, \& Abubakar, 2020; Larsson, 2020). Thus, while refugee status and non-refoulement could assist more people as climate impacts intensify and trigger greater cross-border displacement from disaster, at the same time political resistance, on the basis that to do so would open the proverbial floodgates to new migrants, may stymie that prospect, despite the legal validity of non-refoulement arguments.

Within the matrix of international legal instruments that govern situations in which individuals are displaced by disaster, human rights forms a common and grounding element. The recent work of the UN Human Rights Committee and the IACtHR, the evolution of language on human rights and displacement from Hyogo to Sendai, the global compact agreements, and more recent UN initiatives (Guterres, 2020) all evidence this trend. States are not recused from meeting their human rights obligations even in situations of public emergency and may be under an obligation to seek external assistance where disaster exceeds the state's capacity to respond. Crucially, the UN Human Rights Committee has clarified that planning and preparedness to address future disasters form part of a state's obligation to uphold the right to life. As climate change exacerbates the frequency and intensity of disasters, states are under an obligation to be prepared, including for the displacement effects.

\section{Acknowledgments}

This article was written with the support of grant funding from the Independent Research Fund Denmark. Thanks are also extended to the editors of this thematic issue for their support, and to Charlotte Brown for her invaluable research assistance.

\section{Conflict of Interests}

The author declares no conflict of interests.

\section{References}

Adger, W. N., Pulhin, J. M., Barnett, J., Dabelko, G. D., Hovelsrud, G. K., Levy, M., . . . Leichenko, R. (2014). Human security. In C. B. Field, V. R. Barros, D. J. Dokken, K. J. Mach, M. D. Mastrandrea, T. E. Bilir, ... L. L. White (Eds.), Climate change 2014: Impacts, adaptation and vulnerability. Part A: Global and sectoral aspects (pp. 755-791). Cambridge: Cambridge University Press.
AF (Kiribati), NZIPT 800413 (New Zealand Immigration and Protection Tribunal 2013).

AH (Sudan) v. Secretary of State, 3 WLR 832, 844 (2007).

American Convention on Human Rights, 1969.

Anderson-Nathe, B., \& Gharabaghi, K. (2017). Trending rightward: Nationalism, xenophobia, and the 2016 politics of fear. Child \& Youth Services, 38(1), 1-3.

Apap, J. (2019). The concept of 'climate refugee': Towards a possible definition. European Parliament Think Tank. Retrieved from https://www.europarl. europa.eu/thinktank/en/document.html?reference= EPRS_BRI(2018)621893

Applicant A v. Minister of Immigration and Multiethnic Affairs, INLR 1, 19 (1998).

Behrman, S., \& Kent, A. (2018). Climate refugees: Beyond the legal impasse. Abingdon and New York, NY: Routledge.

Bohra-Mishra, P., Oppenheimer, M., \& Hsiang, S. M. (2014). Nonlinear permanent migration response to climatic variations but minimal response to disasters. Proceedings of the National Academy of Sciences, 111(27), 9780-9785.

Budayeva and Others v. Russian Federation, Application Nos. 15339/02, 21166/02, 20058/02, 11673/02 and 15343/02 (European Court of Human Rights, 2008).

Cannon, T. (1994). Vulnerability analysis and the explanation of 'natural' disasters. In A. Varley (Ed.), Disasters, development and environment (pp. 14-30). Chichester: John Wiley \& Sons.

Cartagena Declaration on Refugees, 1984, Colloquium on the International Protection of Refugees in Central America, Mexico and Panama.

Charter of the United Nations, 1945.

Convention Governing Certain Aspects of Refugee Problems in Africa, 1969, 1001 UNTS 45.

Convention on the Rights of Persons with Disabilities, 2006, UN Doc. A/RES/61/106, Annex I.

Convention Relating to the Status of Refugees, 1951, 189 UNTS 137.

Declaration on the Rights of Peasants and Other People Working in Rural Areas, 2018, UN Doc A/RES/73/165, Annex.

Devakumar, D., Shannon, G., Bhopal, S. S., \& Abubakar, I. (2020). Racism and discrimination in Covid-19 responses. The Lancet, 395(10231), 1194.

Docherty, B., \& Giannini, T. (2009). Confronting a rising tide: A proposal for a convention on climate change refugees symposium. Harvard Environmental Law Review, 33(2), 349-404.

Doyle, T., \& Chaturvedi, S. (2011). Climate refugees and security: Conceptualisations, categories and contestations. In J. Dryzek \& R. B. Norgaard (Eds.), The Oxford handbook of climate change and society (pp. 278-291). Oxford: Oxford University Press.

European Convention on Human Rights, 1950, as amended by Protocols Nos. 11 and 14, ETS 5.

Farbotko, C. (2017). Representation and misrepresentation of climate migrations. In Mayer, B. \& Crépeau, F. 
(Eds.), Research handbook on climate change, migration and the law (pp. 67-84). Cheltenham: Edward Elgar.

Fatemi, F., Ardalan, A., Aguirre, B., Mansouri, N., \& Mohammadfam, I. (2017). Social vulnerability indicators in disasters: Findings from a systematic review. International Journal of Disaster Risk Reduction, 22, 219-227.

Global Compact on Refugees, 2018, UN Doc A/73/12, Part II.

Global Compact for Safe, Orderly and Regular Migration, 2018, UN Doc A/RES/73/195.

Gregory, D. (2009). Imaginative geographies. In D. Gregory, R. Johnston, G. Pratt, M. Watts, \& S. Whatmore (Eds.), The dictionary of human geography (5th. ed., pp. 369-371). Chicester: Wiley-Blackwell.

Guterres, A. (2020). The highest aspiration: A call to action for human rights. Geneva: United Nations. Retrieved from https://www.un.org/sg/sites/www. un.org.sg/files/atoms/files/The_Highest_Asperation _A_Call_To_Action_For_Human_Right_English.pdf

Hoffman, M. (2000). Towards an international disaster response law. In World disasters report 2000 (pp. 144-157). Geneva: International Federation of the Red Cross and Red Crescent Societies.

Inter-American Court of Human Rights. (2017). The environment and human rights (state obligations in relation to the environment in the context of the protection and guarantee of the rights to life and to personal integrity: Interpretation and scope of articles 4(1) and 5(1) of the American convention on human rights) (Advisory Opinion OC-23/18). San José: InterAmerican Court of Human Rights.

International Covenant on Civil and Political Rights, 1966, 999 UNTS 171.

Internal Displacement Monitoring Centre. (2020a). Global report on internal displacement. Geneva: Internal Displacement Monitoring Centre. Retrieved from https://www.internal-displacement.org/sites/ default/files/publications/documents/2020-IDMCGRID.pdf

Internal Displacement Monitoring Centre. (2020b). The displacement continuum. Geneva: Internal Displacement Monitoring Centre. Retrieved from https://www.internal-displacement.org/sites/ default/files/publications/documents/202006cross-border-report.pdf

International Law Commission. (2016). Draft articles on the protection of persons in the event of disasters, with commentaries. Geneva: International Law Commission. Retrieved from https://legal. un.org/ilc/texts/instruments/english/commentaries/ 6_3_2016.pdf

International Organization for Migration. (2019, November 15). IOM tracks repatriations of Haitian migrants from The Bahamas [Press Release]. Retrieved from https://www.iom.int/news/iom-tracks-repatriationshaitian-migrants-bahamas
Joseph, S., \& Castan, M. (2013). The international covenant on civil and political rights (3rd ed.). Oxford: Oxford University Press.

Koh, H. H., Chayes, A., Chayes, A. H., \& Franck, T. M. (1997). Why do nations obey international law? The Yale Law Journal, 106(8), 2599.

Kolmannskog, V., \& Trebbi, L. (2010). Climate change, natural disasters and displacement: A multi-track approach to filling the protection gaps. International Review of the Red Cross, 92(879), 713-730.

Kuusipalo, R. (2016). Exiled by emissions: Climate change related displacement and migration in international law-Gaps in global governance and the role of the UN Climate Convention. Vermont Journal of Environmental Law, 18(4), 614-647.

Larsson, P. (2020, March 31). Anti-Asian racism during coronavirus: How the language of disease produces hate and violence. The Conversation. Retrieved from http://theconversation.com/anti-asian-racismduring-coronavirus-how-the-language-of-diseaseproduces-hate-and-violence-134496

Lauta, K. C. (2015). Disaster law. Oxford and New York, NY: Routledge.

Mayer, B. (2011). The international legal challenges of climate-induced migration: Proposal for an international legal framework. Colorado Journal of International Environmental Law and Policy, 22(3), 357-416.

Mayer, B. (2013). Constructing climate migration as a global governance issue: Essential flaws in the contemporary literature. McGill International Journal of Sustainable Development Law and Policy, 9(1), 87-118.

Mayer, B. (2018). Who are "climate refugees"? Academic engagement in the post-truth era. In S. Behrman \& A. Kent (Eds.), 'Climate refugees:' Beyond the legal impasse (pp. 89-100). Abingdon and New York, NY: Routledge.

McAdam, J. (2011). Swimming against the tide: Why a climate change displacement treaty is not the answer. International Journal of Refugee Law, 23(1), 2-27.

McAdam, J. (2012). Climate change, forced migration, and international law. Oxford: Oxford University Press.

McAdam, J. (2016). From the Nansen Initiative to the Platform on Disaster Displacement. University of New South Wales Law Journal, 39(4), 1518-1546.

McAdam, J. (2020). Protecting people displaced by climate change: The UN Human Rights Committee and the principle of non-refoulement. American Journal of International Law, 114(4), 708-725.

McDonnell, T. (2019, January 24). Climate change creates a new migration crisis for Bangladesh. National Geographic. Retrieved from https://www. nationalgeographic.com/environment/2019/01/ climate-change-drives-migration-crisis-inbangladesh-from-dhaka-sundabans

McLeman, R. (2018). Thresholds in climate migration. Population and Environment, 39(4), 319-338. 
Monsoon destroys Rohingya shelters, sparking record UN emergency food agency response in Bangladesh. (2019, September 13). UN News. Retrieved from https://news.un.org/en/story/2019/09/1046252

Nansen Initiative. (2015). Agenda for the protection of cross-border displaced persons in the context of disasters and climate change. Geneva: Nansen Initiative.

New York Declaration for Refugees and Migrants, 2016, UN Doc. A/RES/71/1.

Nishimura, L. (2015). 'Climate change migrants': Impediments to a protection framework and the need to incorporate migration into climate change adaptation strategies. International Journal of Refugee Law, 27(1), 107-134.

Öneryildiz v. Turkey, Application No. 48939/99 (European Court of Human Rights 2004).

Philip, T. (2018). Climate change displacement and migration: An analysis of the current international legal regime's deficiency, proposed solutions and a way forward for Australia. Melbourne Journal of International Law, 19(2), 639-665.

Pörtner, H.-O., Roberts, D. C., Masson-Delmotte, V., Zhai, P., Tignor, M., Poloczanska, E., ... Weyer, N. M. (Eds.). (2019). The ocean and cryosphere in a changing climate. Geneva: Intergovernmental Panel on Climate Change.

Prieur, M. (2018). Towards an international legal status of environmentally displaced persons. In S. Behrman \& A. Kent (Eds.), 'Climate refugees:' Beyond the legal impasse (pp. 233-242). Abingdon and New York, NY: Routledge.

Rigaud, K. K., Jones, B., Bergmann, J., Clement, V., Ober, K., Schewe, J., . . . Midgley, A. (2018). Groundswell: Preparing for internal climate migration. Washington, DC: World Bank.

Sarkar, S. (2020, May 25). Cyclone Amphan puts focus back on millions displaced by climate disasters. Mongabay. Retrieved from https://india.mongabay. com/2020/05/analysis-cyclone-amphan-puts-focusback-on-millions-displaced-by-climate-disasters

Sendai Framework for Disaster Risk Reduction 2015-2030, 2015.

Silingardi, S. (2012). The status of emergency workers. In A. de Guttry, M. Gestri, \& G. Venturini (Eds.), International disaster response law (pp. 551-583). The Hague: T. M. C. Asser Press.

Simperingham, E. (2017). State responsibilty to prevent climate displacement: The importance of housing, land and property rights. In D. Manou, A. Baldwin, D. Cubie, A. Mihr, \& T. Thorp (Eds.), Climate change, migration and human rights (pp. 86-98). Oxford and New York, NY: Routledge.

Kelly, F. (2019, December 24). Syrian refugee camps inundated with floods making tents uninhabitable [Audio podcast]. Retrieved from https://www.abc.net.au/ radionational/programs/breakfast/11824744

Tampere Convention on the Provision of Telecommunication Resources for Disaster Mitigation and Relief
Operations, 1998, 2296 UNTS 5.

United Nations. (2020, February 27). UN SecretaryGeneral's high-level panel on internal displacement concludes its first meeting. United Nations. Retrieved from https://www.un.org/internal-displacementpanel/news/27-february-2020-un-secretary-general \%E2\%80\%99s-high-level-panel-internaldisplacement-concludes-its

United Nations Framework Convention on Climate Change. (n.d.). Terms of reference: Taskforce on Displacement. Retrieved from https://unfccc.int/ files/adaptation/groups_committees/loss_and_ damage_executive_committee/application/pdf/ tor_task_force_final.pdf

United Nations Framework Convention on Climate Change. (2011). Report of the conference of the parties on its sixteenth session (UN Doc. FCCC/CP) 2010/7/Add.1). Bonn: UN Framework Convention on Climate Change.

United Nations Framework Convention on Climate Change. (2015). Report of the conference of the parties on its twenty-first session (UN Doc. FCCC/CP/ 2015/10/Add.1). Bonn: UN Framework Convention on Climate Change.

United Nations General Assembly. (1949). Statute of the International Law Commission and other resolutions of the General Assembly in relation to the International Law Commission. Lake Success: United Nations General Assembly.

United Nations General Assembly. (2016). Report of the open-ended intergovernmental expert working group on indicators and terminology relating to disaster risk reduction. New York, NY: United Nations General Assembly.

United Nations General Assembly, Sixth Committee. (2019). Summary record of the 35th Meeting (UN GAOR, 6th Comm, 35th mtg, Agenda Item 90, UN Doc A/C.6/73/L.26). New York, NY: United Nations General Assembly, Sixth Committee.

United Nations Human Rights Committee. (2004). General comment No. 31: The nature of the general legal obligation imposed on states parties to the covenant. Geneva: United Nations Human Rights Committee.

United Nations Human Rights Committee. (2018). General comment No. 36: Article 6-Right to life. Geneva: United Nations Human Rights Committee.

United Nations Human Rights Committee. (2020). Views adopted by the committee under article 5(4) of the optional protocol, concerning communication No. 2728/2016. Geneva: United Nations Human Rights Committee.

United Nations Secretary-General. (2019, December 3). High-level panel on internal displacement. United Nations Secretary-General. Retrieved from https://www.un.org/sg/en/content/sg/personnelappointments/2019-12-03/high-level-panelinternal-displacement

Weerasinghe, S. (2018). In harm's way: International pro- 
tection in the context of nexus dynamics between conflict or violence and disaster or climate change (PPLA/2018/05). Geneva: UNHCR.

$\mathrm{Xu}, \mathrm{C} ., \mathrm{K}$ Kohler, T. A., Lenton, T. M., Svenning, J.-C., \& Scheffer, M. (2020). Future of the human climate niche. Proceedings of the National Academy of Sciences, $117(21), 11350-11355$.
Zetter, R., \& Morrissey, J. (2014). The environmentmobility nexus: Reconceptualizing the links between environmental stress, (im)mobility, and power. In E. Fiddian-Qasmiyeh, G. Loescher, K. Long, \& N. Sigona (Eds.), The Oxford handbook of refugee and forced migration studies (pp. 342-354). Oxford: Oxford University Press.

\section{About the Author}

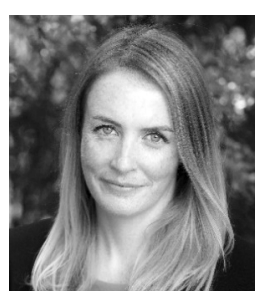

Miriam Cullen is Assistant Professor of Climate and Migration Law at Copenhagen University's Faculty of Law and a member of the Advisory Committee to the Platform on Disaster Displacement. Her research interests include international law, climate and disaster-related displacement and mobility, human rights, especially the rights of minorities, and the law and practice of the United Nations and other international institutions. 